\title{
SMALL NEWSPAPERS, BIG CHANGES: AWARENESS \\ OF MARKET-DRIVEN JOURNALISM AND CONSEQUENCES FOR COMMUNITY NEWSPAPERS
}

\author{
Richard Robert Gross \\ Dr. Glen Cameron, Dissertation Supervisor
}

\begin{abstract}
This study examines the attitudes of journalists at small newspapers toward market-driven journalism. The researcher queried 29 journalists at nine small Missouri newspapers.

The author employed qualitative method using several data sets to examine the possible relationship among certain phenomena related to the question of market-driven journalism at small newspapers. How is marketdriven journalism perceived by editorial employees at small newspapers; to what extent do financial considerations guide their newspapers' coverage of their communities; and, how well does the newspaper content reflect the composition and concerns of the respective communities?

The study concludes that journalists at small newspapers do have an understanding of the impact of market-driven journalism, that financial considerations do have an impact on news coverage by these newspapers to varying degrees depending on the resources of the newspaper, and that community newspapers do not adequately represent the composition of their communities, particularly new and growing population segments.
\end{abstract}

